\title{
Reese-Ellsworth Classification IIIA
}

National Cancer Institute

\section{Source}

National Cancer Institute. Reese-Ellsworth Classification IIIA. NCI Thesaurus. Code C123372.

Any lesion anterior to the equator. 